\title{
New 2,6,9-trisubstituted adenines as adenosine receptor antagonists: a preliminary SAR profile
}

\author{
Catia Lambertucci • Gloria Cristalli • Diego Dal Ben • \\ Dhuldeo D. Kachare • Chiara Bolcato • \\ Karl-Norbert Klotz • Giampiero Spalluto • \\ Rosaria Volpini
}

Received: 20 July 2007 / Accepted: 31 July 2007 / Published online: 19 September 2007

(C) Springer Science + Business Media B.V. 2007

\begin{abstract}
A new series of 2,6,9-trisubstituted adenines (514) have been prepared and evaluated in radioligand binding studies for their affinity at the human $A_{1}, A_{2 A}$ and $\mathrm{A}_{3}$ adenosine receptors and in adenylyl cyclase experiments for their potency at the human $\mathrm{A}_{2 \mathrm{~B}}$ subtype. From this preliminary study the conclusion can be drawn that introduction of bulky chains at the $N^{6}$ position of 9propyladenine significantly increased binding affinity at the human $A_{1}$ and $A_{3}$ adenosine receptors, while the presence of a chlorine atom at the 2 position resulted in a not univocal effect, depending on the receptor subtype and/or on the substituent present in the $N^{6}$ position. However, in all cases, the presence in the 2 position of a chlorine atom
\end{abstract}

C. Lambertucci $\cdot$ G. Cristalli $\cdot$ D. Dal Ben •

D. D. Kachare $\cdot$ R. Volpini

Department of Chemical Sciences, University of Camerino,

62032 Camerino, Italy

C. Bolcato $\cdot$ G. Spalluto

Department of Pharmaceutical Sciences,

University of Trieste,

34127 Trieste, Italy

K.-N. Klotz

Institut für Pharmakologie und Toxikologie,

Universität Würzburg,

97078 Würzburg, Germany

G. Spalluto $(\bowtie)$

Dipartimento di Scienze Farmaceutiche,

p.le Europa, 1,

34127 Trieste, Italy

e-mail: spalluto@units.it

R. Volpini $(\bowtie)$

Dipartimento di Scienze Chimiche,

via S. Agostino, 1 ,

62032 Camerino, Italy

e-mail: rosaria.volpini@unicam.it favoured the interaction with the $\mathrm{A}_{2 \mathrm{~A}}$ subtype. These results demonstrated that, although the synthesized compounds were found to be quite inactive at the human $A_{2 B}$ subtype, adenine is a useful template for further development of simplified adenosine receptor antagonists with distinct receptor selectivity profiles.

Keywords Adenine derivatives · Adenosine receptors · Adenosine receptor antagonists $\cdot$ Adenosine receptor ligands $\cdot G$ protein-coupled receptors

\section{Introduction}

Adenosine, a naturally occurring nucleoside, is involved in a wide variety of physiological and pathophysiological processes [1]. Adenosine mediates these effects through the activation of at least four human receptor subtypes (P1), belonging to the superfamily of $\mathrm{G}$ protein-coupled receptors, which have been recently cloned [2] and classified as $\mathrm{A}_{1}, \mathrm{~A}_{2 \mathrm{~A}}, \mathrm{~A}_{2 \mathrm{~B}}$ and $\mathrm{A}_{3}$ [3]. The subtypes are classified on the bases of coupling to second messengers and pharmacological profiles for agonists and antagonists. In fact, $A_{1}$ and $A_{3}$ adenosine receptor subtypes are linked to inhibition of adenylyl cyclase and $\mathrm{A}_{2 \mathrm{~A}}$ and $\mathrm{A}_{2 \mathrm{~B}}$ subtypes are linked to stimulation of the same enzyme [4].

In particular, $A_{2 B}$ receptors have been implicated in several physiological functions such as the regulation of mast cell secretion $[5,6]$, gene expression $[5,7,8]$, cell growth [9] and intestinal functions. $A_{2 B}$ receptors may also play a role in asthma, since they mediate mast cell degranulation from human mast cells and are present in high density in human blood eosinophils [10,11]. For this reason $\mathrm{A}_{2 \mathrm{~B}}$ antagonists could be considered potential antiasthmatic agents [10-12]. While the $A_{1}, A_{2 A}$ and $A_{3}$ 
adenosine receptors have been pharmacologically characterized through the use of highly potent and selective agonists and/or antagonists, an accurate investigation of the pathophysiological role of $A_{2 B}$ receptors is precluded due to the lack of very selective ligands [13]. On the other hand, only recently radiolabelled adenosine antagonists have been used for binding assays at the $A_{2 B}$ receptor subtype [1]. Recently, xanthine derivatives, such as compounds $\mathbf{1}$ and $\mathbf{2}$ in Fig. 1, have been proposed as potent and selective adenosine receptor antagonists $[14,15]$. On the other hand, in the non-xanthine family poor results have been obtained in recent years. However, mention should be made of the pyrazolo-triazolo-pyrimidine derivative $\mathbf{3}$, which showed promising binding affinity at the $\mathrm{A}_{2 \mathrm{~B}}$ adenosine receptor although the level of selectivity vs the human (h) $A_{3}$ subtype was still poor [16]. Very recently, a bipyrimidyl derivative 4 has been proposed as an $A_{2 B}$ adenosine receptor antagonist, with affinity in the same range of compound 3, while the selectivity vs the other receptor subtypes was found to be significantly better [17] (Fig. 1).

A structural analysis of the derivatives $\mathbf{1}$ and $\mathbf{3}$ clearly shows the presence of bulky substituents such as arylox- yacetylamino-phenyl groups at the 8 position (compound $\mathbf{1}$ ) and arylacetyl moiety at the N5 position (compound $\mathbf{3}$ ).

On the other hand, in recent years a number of substituted adenines have been synthesized and tested at the four adenosine receptor subtypes, demonstrating that the introduction of different substituents at the 2,8 and 9 positions of the adenine core resulted in high-affinity antagonists with distinct receptor selectivity profile [18-22]. At the $\mathrm{A}_{2 \mathrm{~B}}$ receptor the derivatives bearing an ethyl in the 9 position and linear chains in the 2 position showed potency in the $\mu \mathrm{M}$ range, while the presence of sterically hindered substituents in the same positions was detrimental for the potency. Furthermore, substitution of the 9-ethyl group with a propyl chain seems to favour the interaction with human $\mathrm{A}_{2 \mathrm{~B}}$ receptors [21].

Hence, on the basis of the results obtained with compound $\mathbf{3}$, introduction of a bulky substituent on the $N^{6}$ amino group of the adenine and 2-chloroadenine moiety could increase potency and selectivity for the human $\mathrm{A}_{2 \mathrm{~B}}$ adenosine receptor subtypes.

Hence, bulky substituents such as arylacetyl or aryloxyphenylacetyl moieties were introduced on the $N^{6}$ amino group of compounds 5 and 6 to obtain derivatives 7-14,
Fig. 1 Structures and binding profile $\left(\mathrm{K}_{\mathrm{i}} \mathrm{nM}\right)$ of some $\mathrm{A}_{2 \mathrm{~B}}$ adenosine receptor antagonists
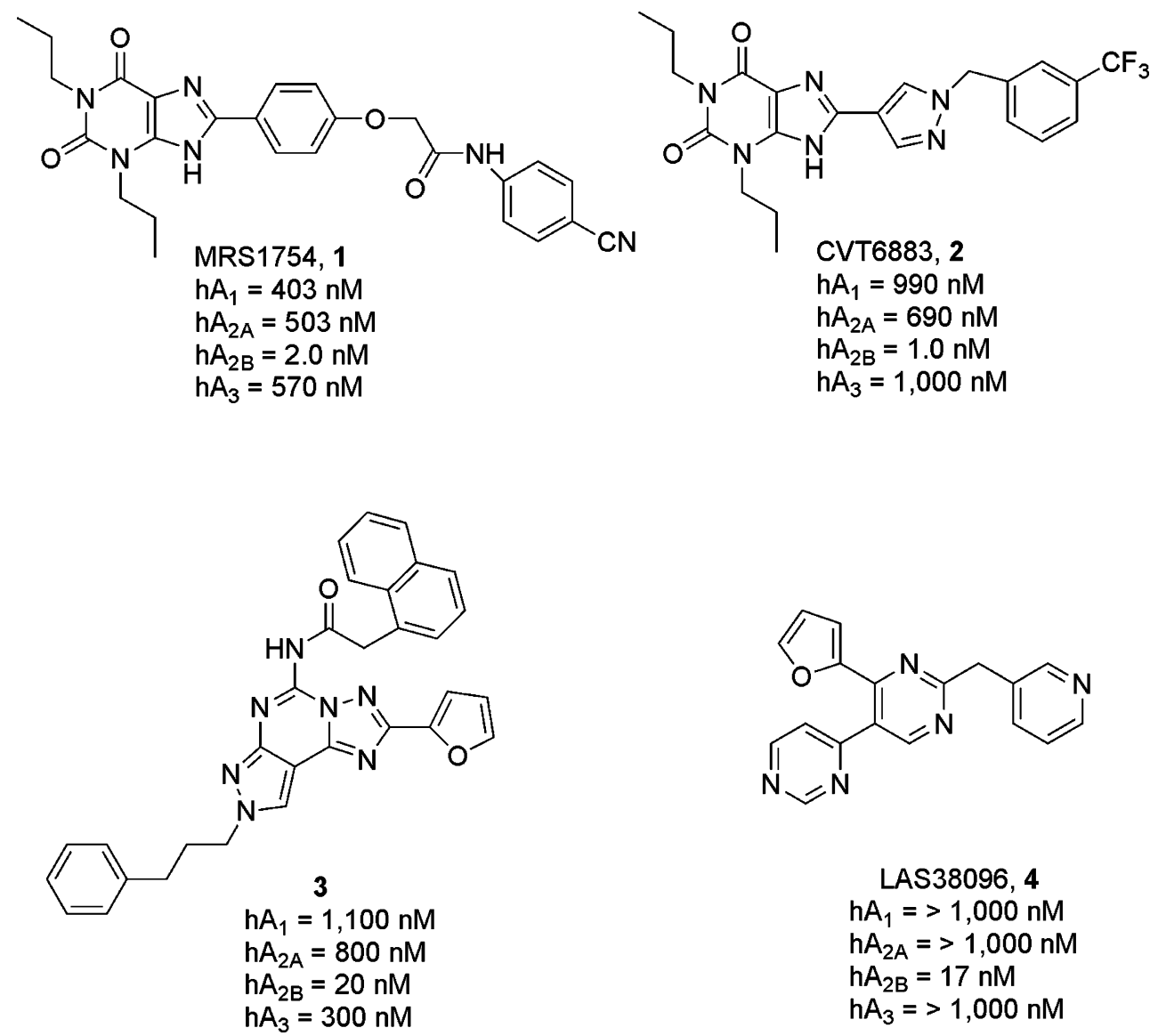

LAS38096, 4

$\mathrm{hA}_{1}=>1,000 \mathrm{nM}$

$\mathrm{hA}_{2 \mathrm{~A}}=>1,000 \mathrm{nM}$

$\mathrm{hA}_{2 \mathrm{~B}}=17 \mathrm{nM}$

$\mathrm{hA}_{3}=>1,000 \mathrm{nM}$ 
with the aim of finding a new class of $\mathrm{A}_{2 \mathrm{~B}}$ antagonists (Fig. 2).

\section{Chemistry}

The designed compounds (5-14) have been synthesized as summarized in Schemes 1 and 2. The starting 9-propyladenine (5) [23] was obtained by alkylation of commercially available adenine (15) with propyliodide in the presence of potassium carbonate. Flash chromatography led to the desired 9-substituted isomer $\mathbf{5}$ as the major product (yield $79 \%$ ) together with the 7-isomer 5a (yield 9\%). Isomeric structure of compounds $\mathbf{5}$ and $\mathbf{5 a}$ was assigned on the bases of $1 \mathrm{D}-{ }^{1} \mathrm{H}-\mathrm{NOE}$ difference spectra. In fact, irradiation of both $\mathrm{CH}_{2}$ groups of the propylic chain in compound $\mathbf{5 a}$ gave a $\mathrm{NOE}$ at both $\mathrm{H}-\mathrm{C}(8)$ and $6-\mathrm{NH}_{2}$ groups, demonstrating the 7 position as the alkylation site. On the contrary, a NOE at both $\mathrm{H}-\mathrm{C}(8)$ and $\mathrm{H}-\mathrm{C}(2)$, and not at the 6- $\mathrm{NH}_{2}$ group in compound $\mathbf{5}$, upon saturation of $\mathrm{CH}_{2}$ groups of the propylic chain, confirmed the 9 position as the alkylation site.

The 2-chloro derivative $\mathbf{6}$ was obtained by alkylation of commercially available 2,6-dichloropurine (16) with propyliodide, using the same procedure utilized for compound $\mathbf{5}$, to afford the 9-substituted isomer $\mathbf{1 7}$ as the major product (yield 75\%) along with the 7-isomer 17a (yield 10\%) [24]. $\left[{ }^{1} \mathrm{H}\right]$-NMR spectra of $\mathbf{1 7}$ and $\mathbf{1 7} \mathbf{a}$ in $\mathrm{CDCl}_{3}$ are in agreement with those reported in the literature [24]; in the experimental part $\left[{ }^{1} \mathrm{H}\right]-\mathrm{NMR}$ spectra of the same compounds are reported using dimethyl sulfoxide (DMSO) as
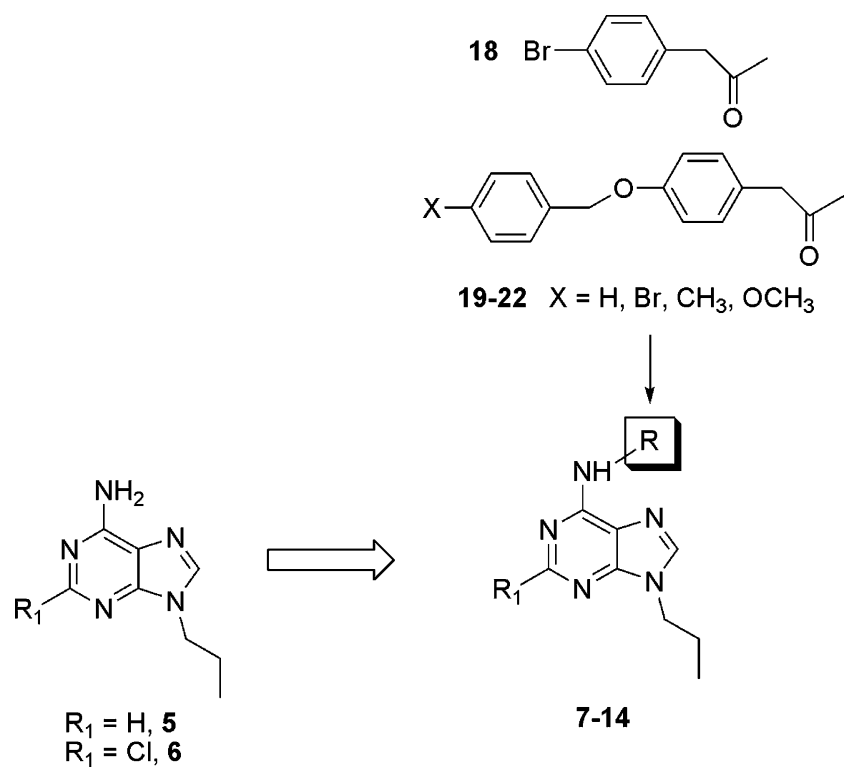

Fig. 2 Structures of designed compounds the solvent. Compound $\mathbf{1 7}$ was reacted with liquid ammonia in a sealed tube at room temperature (RT) overnight to give the 2-chloro-9-propyladenine (6) [24] (Scheme 1).

Final compounds 7-14 were obtained by condensation of amino compounds 5 or 6 with the appropriate acid 18-22 [25] in the presence of carbonyldiimidazole in tetrahydrofurane (THF) at reflux for $18 \mathrm{~h}$ (Scheme 2).

\section{Results and discussion}

All the compounds were evaluated at the human recombinant adenosine receptors, stably transfected into Chinese hamster ovary $(\mathrm{CHO})$ cells, utilizing radioligand binding studies $\left(\mathrm{A}_{1}, \mathrm{~A}_{2 \mathrm{~A}}, \mathrm{~A}_{3}\right)$ or adenylyl cyclase activity assay $\left(\mathrm{A}_{2 \mathrm{~B}}\right)$. Receptor binding affinity was determined using $\left[{ }^{3} \mathrm{H}\right]$ CCPA (2-chloro- $N^{6}$-cyclopentyladenosine) as the radioligand for $\mathrm{A}_{1}$ receptors, whereas $\left[{ }^{3} \mathrm{H}\right] \mathrm{NECA}\left(5^{\prime}-\mathrm{N}\right.$-ethylcarboxamidoadenosine) was used for the $A_{2 A}$ and $A_{3}$ subtypes. In the case of $A_{2 B}$ receptors $K_{i}$ values were calculated from $\mathrm{IC}_{50}$ values determined by inhibition of NECA-stimulated adenylyl cyclase activity. $K_{i}$ values are in $\mu \mathrm{M}$, with $95 \%$ confidence intervals in parentheses [26]. The results of binding and cyclase activity studies are reported in Table 1.

All the tested compounds 5-14 showed affinities at the human $\mathrm{A}_{1}, \mathrm{~A}_{2 \mathrm{~A}}$ and $\mathrm{A}_{3}$ adenosine receptors in the $\mu \mathrm{M}$ range without significant levels of selectivity. At $\mathrm{A}_{2 \mathrm{~B}}$ receptors most compounds were found to be inactive when tested at a concentration up to $100 \mu \mathrm{M}\left(\mathrm{K}_{\mathrm{i}}\right.$ values > $30 \mu \mathrm{M})$. It is quite evident that the introduction of phenylacetic or aryloxyphenylacetic moieties at the $N^{6}$ position of 9-propyladenine (5) or of 2-chloro-9-propyladenine (6) to give compounds 7-14 modifies the binding profile of the derivatives, although without significantly increasing binding affinity (Table 1). On the other hand, the same substitutions were found to be detrimental for the activity at the $\mathrm{A}_{2 \mathrm{~B}}$ receptor subtype. In fact, the $N^{6}$ unsubstituted derivative $\mathbf{6}$ proved to be the most potent of the series with $\mathrm{K}_{\mathrm{i}} \mathrm{A}_{2 \mathrm{~B}}=11 \mu \mathrm{M}$.

The effect of the chlorine at the 2 position on binding affinity at the adenosine receptors it is not univocal, depending on the receptor subtype and/or on the substituent in $N^{6}$. Analysis of the binding profile of the $N^{6}$-unsubstituted derivatives in more detail revealed that the presence of a chlorine atom at the 2 position (compound 6 ) increased the affinity $\left(\mathrm{A}_{1}, \mathrm{~A}_{2 \mathrm{~A}}\right.$ and $\left.\mathrm{A}_{3}\right)$ and potency $\left(\mathrm{A}_{2 \mathrm{~B}}\right)$ at adenosine receptors two- to threefold compared with the unsubstituted analogue $\mathbf{5}$.

A quite similar profile could be observed when a 4bromophenylacetic group was introduced at the $N^{6}$ position (compare compound $\mathbf{8}$ with $\mathbf{7}$ ). 
Scheme 1 a Synthesis of

9-propyladenine; b Synthesis of

2-chloro-9-propyladenine.

Reagents: i: DMF, $\mathrm{K}_{2} \mathrm{CO}_{3}$, propyliodide, RT; ii: liq. $\mathrm{NH}_{3}$, sealed tube, RT

a<smiles>CC(C)C</smiles>

15<smiles>CCCn1cnc2c(N)ncnc21</smiles>

b<smiles>Clc1nc(Cl)c2nc[nH]c2n1</smiles>

16

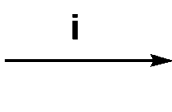<smiles>CCn1cnc2c(Cl)nc(Cl)nc21</smiles><smiles>CCCn1cnc2nc(Cl)nc(Cl)c21</smiles>

$17 \mathbf{a}$<smiles>CCCn1cnc2c(N)nc(Cl)nc21</smiles>

An opposite effect of the chlorine atom was detected at $A_{1}, A_{2 B}$ and $A_{3}$ receptors when a bulkier substituent, such as the 4-aryloxyphenylacetic chain, was introduced at the $N^{6}$ position. In fact, this kind of combination significantly reduced or did not modify the $A_{1}$ and $A_{3}$ affinity and the $\mathrm{A}_{2 \mathrm{~B}}$ potency $\left(9: \mathrm{K}_{\mathrm{i}} \mathrm{A}_{1}=1.4 \mu \mathrm{M}, \mathrm{K}_{\mathrm{i}} \mathrm{A}_{2 \mathrm{~B}}>\right.$ $30 \mu \mathrm{M}, \mathrm{K}_{\mathrm{i}} \mathrm{A}_{3}=5.3 \mu \mathrm{M}$ vs 10: $\mathrm{K}_{\mathrm{i}} \mathrm{A}_{1}=26 \mu \mathrm{M}, \mathrm{K}_{\mathrm{i}} \mathrm{A}_{2 \mathrm{~B}}>$ $30 \mu \mathrm{M}, \mathrm{K}_{\mathrm{i}} \mathrm{A}_{3}=4.9 \mu \mathrm{M}$ and 12: $\mathrm{K}_{\mathrm{i}} \mathrm{A}_{1}=13 \mu \mathrm{M}, \mathrm{K}_{\mathrm{i}} \mathrm{A}_{2 \mathrm{~B}}=$ $22 \mu \mathrm{M}, \mathrm{K}_{\mathrm{i}} \mathrm{A}_{3}=10 \mu \mathrm{M}$ vs 13: $\mathrm{K}_{\mathrm{i}} \mathrm{A}_{1}=22 \mu \mathrm{M}, \mathrm{K}_{\mathrm{i}} \mathrm{A}_{2 \mathrm{~B}}>$ $\left.30 \mu \mathrm{M}, \mathrm{K}_{\mathrm{i}} \mathrm{A}_{3}=19 \mu \mathrm{M}\right)$.

However, in all cases, the presence of a chlorine atom in the 2 position favoured the interaction with the $\mathrm{A}_{2 \mathrm{~A}}$ subtype (compare $A_{2 A}$ affinity of 5, 7, 9 and 12 with $\mathbf{6 , 8}$, 10 and 13, respectively), while the presence of any substituent on the $N^{6}$ position seems to somewhat reduce the affinity. In fact the compound endowed with the highest $\mathrm{A}_{2 \mathrm{~A}}$ affinity proved to be the 2-chloro-9-propyladenine $\left(6: \mathrm{K}_{\mathrm{i}} \mathrm{A}_{2 \mathrm{~A}}=2.2 \mu \mathrm{M}\right)$. These findings are in agreement with previous observations related to adenosine analogues strongly suggesting that the introduction of substituents in the $N^{6}$ position dramatically reduces the $\mathrm{A}_{2 \mathrm{~A}}$ affinity [27-32].

Nevertheless, it should be underlined that the presence of a bulky chain at the $N^{6}$ position significantly increased (20- to

Scheme 2 Reagents: i: CDI, dry THF, reflux<smiles>[R][R]#[R][H]</smiles>

$\mathrm{R}-\mathrm{COOH}$

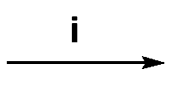

18-22<smiles>[R]Nc1nc([R])nc2c1ncn2CCC</smiles>

7-14 
Table 1 Biological profile of synthesized compounds 5-14

\begin{tabular}{|c|c|c|c|c|c|c|}
\hline Compd & $\mathbf{R}_{\mathbf{I}}$ & $\mathbf{R}$ & $\mathbf{h} \mathbf{A}_{1}\left(\mathbf{K}_{\mathbf{i}} \mu \mathbf{M}\right)^{\mathbf{a}}$ & $\mathbf{h} \mathbf{A}_{2 A}\left(\mathbf{K}_{\mathbf{i}} \mu \mathbf{M}\right)^{\mathbf{b}}$ & $\mathbf{h} \mathbf{A}_{2 B}\left(K_{i} \mu M\right)^{\mathbf{c}}$ & $\mathbf{h} \mathbf{A}_{3}\left(\mathbf{K}_{\mathbf{i}} \mu \mathbf{M}\right)^{\mathbf{d}}$ \\
\hline 5 & $\mathrm{H}$ & $\mathrm{H}$ & $\begin{array}{c}24 \\
(\mathrm{I} 8-32)\end{array}$ & $\begin{array}{c}5 \cdot \mathrm{I} \\
(4.2-6.2)\end{array}$ & $\begin{array}{c}22 \\
(\mathrm{I} 3-37)\end{array}$ & $>\mathrm{IOO}$ \\
\hline 6 & $\mathrm{Cl}$ & $\mathrm{H}$ & $\begin{array}{c}8.4 \\
(6 . \mathrm{I}-\mathrm{II})\end{array}$ & $\begin{array}{c}2.2 \\
(2.0-2.3)\end{array}$ & $\begin{array}{c}\text { I I } \\
(6.6-\mathrm{I} 8)\end{array}$ & $\begin{array}{c}27 \\
(23-32)\end{array}$ \\
\hline 7 & $\mathrm{H}$ & 4-Br-Ph- $\mathrm{CH}_{2}-\mathrm{CO}$ & $\begin{array}{c}22 \\
(19-24)\end{array}$ & $\begin{array}{c}\text { IO } \\
(8.6-\mathrm{I} 2)\end{array}$ & $>30$ & $\begin{array}{c}3 I \\
(27-36)\end{array}$ \\
\hline 8 & $\mathrm{Cl}$ & 4-Br-Ph- $\mathrm{CH}_{2}-\mathrm{CO}$ & $\begin{array}{c}5.2 \\
(3.7-7.6)\end{array}$ & $\begin{array}{c}3 \cdot 7 \\
(2.9-4.9)\end{array}$ & $\begin{array}{c}\text { I9 } \\
(\mathrm{I} 6-22)\end{array}$ & $\begin{array}{c}\text { IO } \\
(7 \cdot 4-\mathrm{I} 5)\end{array}$ \\
\hline 9 & $\mathrm{H}$ & & $\begin{array}{c}\mathrm{I} .4 \\
(0.96-2 . \mathrm{I})\end{array}$ & $\begin{array}{c}8.9 \\
(7.2-\mathrm{II})\end{array}$ & $>30$ & $\begin{array}{c}5 \cdot 3 \\
(2.9-9.6)\end{array}$ \\
\hline I0 & $\mathrm{Cl}$ & & $\begin{array}{c}26 \\
(24-28)\end{array}$ & $\begin{array}{c}6.2 \\
(3.6-\mathrm{II})\end{array}$ & $>30$ & $\begin{array}{c}4.9 \\
(3.8-6.3)\end{array}$ \\
\hline I I & $\mathrm{H}$ & & $\begin{array}{c}\text { I I } \\
(8.5-\mathrm{I} 4)\end{array}$ & $\begin{array}{c}\text { I2 } \\
(\mathrm{IO}-\mathrm{I} 4)\end{array}$ & $>30$ & $\begin{array}{c}\mathrm{I} .4 \\
\text { (I.I-2.0) }\end{array}$ \\
\hline $\mathbf{I} 2$ & $\mathrm{H}$ & & $\begin{array}{c}\mathrm{I} 3 \\
(\mathrm{IO}-\mathrm{I} 7)\end{array}$ & $\begin{array}{c}\mathrm{I} 2 \\
(\mathrm{IO}-\mathrm{I} 4)\end{array}$ & $\begin{array}{c}22 \\
(20-24)\end{array}$ & $\begin{array}{c}\text { IO } \\
(8 . \mathrm{I}-\mathrm{I} 3)\end{array}$ \\
\hline $\mathbf{I 3}$ & $\mathrm{Cl}$ & & $\begin{array}{c}22 \\
(\mathrm{I} 8-28)\end{array}$ & $\begin{array}{c}6.6 \\
(5.8-7 \cdot 5)\end{array}$ & $>30$ & $\begin{array}{c}\text { I9 } \\
(\mathrm{I} 4-26)\end{array}$ \\
\hline I4 & $\mathrm{Cl}$ & & $\begin{array}{c}26 \\
(\mathrm{I} 6-42) \\
\end{array}$ & $\begin{array}{c}6.5 \\
\left(3 \cdot 3^{-I} 3\right) \\
\end{array}$ & $>30$ & $\begin{array}{c}\mathrm{I} 4 \\
(8.8-22) \\
\end{array}$ \\
\hline
\end{tabular}

${ }^{a}$ Displacement of specific $\left[{ }^{3} \mathrm{H}\right]$-CCPA binding at human $\mathrm{A}_{1}$ receptors expressed in CHO cells. ${ }^{b}$ Displacement of specific $\left[{ }^{3} \mathrm{H}\right]-\mathrm{NECA}$ binding at human $\mathrm{A}_{2 \mathrm{~A}}$ receptors expressed in $\mathrm{CHO}$ cells. ${ }^{\mathrm{c}} \mathrm{K}_{\mathrm{i}}$ values of the inhibition of NECA-stimulated adenylyl cyclase activity in CHO cells expressing human $\mathrm{A}_{2 \mathrm{~B}}$ receptors. ${ }^{\mathrm{d}}$ Displacement of specific $\left[{ }^{3} \mathrm{H}\right]-\mathrm{NECA}$ binding at human $\mathrm{A}_{3}$ receptors expressed in $\mathrm{CHO}$ cells.

70-fold) the affinity at the $\mathrm{A}_{1}$ and $\mathrm{A}_{3}$ subtypes in comparison with 9-propyladenine (9: $\mathrm{K}_{\mathrm{i}} \mathrm{A}_{1}=1.4 \mu \mathrm{M}$ and 11: $\mathrm{K}_{\mathrm{i}} \mathrm{A}_{3}=$ $1.4 \mu \mathrm{M}$ vs 5: $\mathrm{K}_{\mathrm{i}} \mathrm{A}_{1}=24 \mu \mathrm{M}$ and $\left.\mathrm{K}_{\mathrm{i}} \mathrm{A}_{3}>100 \mu \mathrm{M}\right)$.

This increase of affinity seems also to be modulated by the substituent on the aryloxyphenylacetic group; in fact, substitution with a lipophilic bromine (9) or methyl group (11) at the para position is responsible for the increased $A_{1}$ and $\mathrm{A}_{3}$ receptor affinity, respectively, while the presence of a hydrogen (12) or a methoxy group (14) did not positively influence the binding profile.

\section{Conclusions}

In conclusion the study herein presented, although it did not reach the proposed goal of obtaining $\mathrm{A}_{2 \mathrm{~B}}$ adenosine receptor antagonists, increased knowledge of the structureactivity relationships in adenine derivatives.

Moreover, it was demonstrated that the introduction of bulky substituents at the $N^{6}$ position of adenine derivatives significantly increased the affinity at the $A_{1}$ and $A_{3}$ adenosine receptors, while the presence of a chlorine atom in the 2 position favoured the interaction with the $A_{2 A}$ subtype. These results demonstrated that, although the synthesized compounds were found to be quite inactive at the human $\mathrm{A}_{2 \mathrm{~B}}$ subtype, adenine is a useful template for further development of simplified adenosine receptor antagonists with distinct receptor selectivity profiles, opening up new chances to design structurally simplified $\mathrm{A}_{1}$ and $\mathrm{A}_{3}$ adenosine receptor antagonists.

\section{Experimental section}

\section{Chemistry}

General: melting points were determined with a Büchi apparatus and are uncorrected. ${ }^{1} \mathrm{H}$ NMR spectra were obtained with Varian VXR $300 \mathrm{MHz}$ spectrometer; $\delta$ in ppm, $J$ in Hz. All exchangeable protons were confirmed by addition of $\mathrm{D}_{2} \mathrm{O}$. Thin layer chromatography (TLC) was carried out on precoated TLC plates with silica gel $60 \mathrm{~F}$ - 
254 (Merck). For column chromatography, silica gel 60 (Merck) was used. Elemental analyses were determined on Fisons Instruments Model EA 1108 CHNS-O model analyser and are within $\pm 0.4 \%$ of theoretical values.

\section{9-Propyladenine (5) and 7-propyladenine (5a)}

To a solution of adenine (15) $(0.5 \mathrm{~g}, 3.7 \mathrm{mmol})$ in dry DMF $(10 \mathrm{ml})$, under nitrogen, $\mathrm{K}_{2} \mathrm{CO}_{3}(0.83 \mathrm{~g}, 5.97 \mathrm{mmol})$ and propyliodide $(0.433 \mathrm{ml}, 4.44 \mathrm{mmol})$ were added. The mixture was stirred at RT for $16 \mathrm{~h}$, then the solvent was removed under reduced pressure and the crude purified by flash chromatography $\left(\mathrm{CHCl}_{3}-\mathrm{MeOH}\right.$ 98:2) to afford 5 [23] and $\mathbf{5 a}$ (yield 79 and $9 \%$, respectively) as white solids, after crystallization from $\mathrm{CH}_{3} \mathrm{OH}$.

5: m.p. $173-175^{\circ} \mathrm{C} .{ }^{1} \mathrm{H}-\mathrm{NMR}\left(\mathrm{DMSO}-d_{6}\right) \delta 0.85(\mathrm{t}, 3 \mathrm{H}$, $\left.J=7.4, \mathrm{CH}_{3}\right) ; 1.82\left(\mathrm{~m}, 2 \mathrm{H}, \mathrm{CH}_{2}-\mathrm{CH}_{3}\right) ; 4.11(\mathrm{t}, 2 \mathrm{H}, J=7.0$, $\mathrm{CH}_{2}-\mathrm{N}$ ); 7.21 (bs, 2H, NH $)_{2}$; 8.15 (s, 2H, H-2 and H-8). Anal. Calcd. for $\mathrm{C}_{5} \mathrm{H}_{5} \mathrm{~N}_{5}(177.2) \mathrm{C}, 54.22 ; \mathrm{H}, 6.26 ; \mathrm{N}$, 39.52; found: C, 54.54; $\mathrm{H}, 6.71 ; \mathrm{N}, 39.33$.

5a: m.p. $>250{ }^{\circ} \mathrm{C}$. ${ }^{1} \mathrm{H}-\mathrm{NMR}\left(\mathrm{DMSO}-d_{6}\right) \delta 0.86$ (t, $3 \mathrm{H}$, $\left.J=7.3, \mathrm{CH}_{3}\right) ; 1.91$ (m, $\left.2 \mathrm{H}, \mathrm{CH}_{2}-\mathrm{CH}_{3}\right) ; 4.26$ (t, $2 \mathrm{H}, J=7.0$, $\mathrm{CH}_{2}-\mathrm{N}$ ); 7.75 (s, $\left.1 \mathrm{H}, \mathrm{H}-2\right) ; 7.85$ (bs, $2 \mathrm{H}, \mathrm{NH}_{2}$ ); 8.34 (s, $1 \mathrm{H}$, H-8). Anal. Calcd. for $\mathrm{C}_{5} \mathrm{H}_{5} \mathrm{~N}_{5}(177.2) \mathrm{C}, 54.22 ; \mathrm{H}, 6.26$; N, 39.52; found: C, 54.45; H, 6.45; N, 39.45 .

\section{2,6-Dichloro-9-propyl-9H-purine (17) and 2,6-dichloro-7- propyl-9H-purine (17a)}

To a solution of 2,6-dichloropurine (16) $(1 \mathrm{~g}, 5.29 \mathrm{mmol})$ in dry DMF (14 ml), under nitrogen, $\mathrm{K}_{2} \mathrm{CO}_{3}(1.18 \mathrm{~g}$, $6.61 \mathrm{mmol})$ and propyliodide $(0.59 \mathrm{ml}, 6.08 \mathrm{mmol})$ were added. The mixture was stirred at RT overnight, then the solvent was removed under reduced pressure and the crude purified by flash chromatography $\left(\mathrm{cC}_{6} \mathrm{H}_{12}\right.$-EtOAc $\left.75: 25\right)$ to afford 17 and 17a as white solids (yield 75 and 10\%, respectively) [24].

17: m.p. $58-59^{\circ} \mathrm{C} ;{ }^{1} \mathrm{H}-\mathrm{NMR}$ (DMSO- $\left.d_{6}\right) \delta 0.86(\mathrm{t}, 3 \mathrm{H}$, $\left.J=7.5 \mathrm{~Hz}, \mathrm{CH}_{2} \mathrm{CH}_{3}\right), 1.85\left(\mathrm{~m}, 2 \mathrm{H}, \mathrm{CH}_{2} \mathrm{CH}_{3}\right), 4.21$ (t, $2 \mathrm{H}$, $\left.J=7.0 \mathrm{~Hz}, \mathrm{~N}-\mathrm{CH}_{2}\right), 8.76(\mathrm{~s}, 1 \mathrm{H}, \mathrm{H}-8)$. Anal. Calcd. for $\mathrm{C}_{8} \mathrm{H}_{8} \mathrm{Cl}_{2} \mathrm{~N}_{4}$ (231.1) C, 41.58; H, 3.49; N, 24.25. Found: C, 41.85; H, 3.70; N, 24.10 .

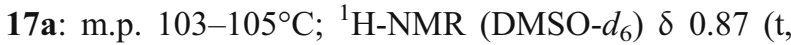
$\left.3 \mathrm{H}, J=7.4 \mathrm{~Hz}, \mathrm{CH}_{2} \mathrm{CH}_{3}\right), 1.84\left(\mathrm{~m}, 2 \mathrm{H}, \mathrm{CH}_{2} \mathrm{CH}_{3}\right), 4.40$ (t, $2 \mathrm{H}, J=7.2 \mathrm{~Hz}, \mathrm{~N}-\mathrm{CH}_{2}$ ), 8.89 (s, $1 \mathrm{H}, \mathrm{H}-8$ ). Anal. Calcd. for $\mathrm{C}_{8} \mathrm{H}_{8} \mathrm{Cl}_{2} \mathrm{~N}_{4}$ (231.1) C, 41.58; H, 3.49; N, 24.25. Found: C, $41.75 ; \mathrm{H}, 3.55 ; \mathrm{N}, 24.19$.

\section{2-Chloro-9-propyladenine (6)}

Liquid ammonia (5 ml) and compound 17 (0.46 g, $1.97 \mathrm{mmol}$ ) were poured into a sealed tube and the resulting mixture was stirred at RT overnight. Ammonia was evaporated and the crude purified by flash chromatography $\left(\mathrm{CHCl}_{3}-\mathrm{MeOH} 99: 1\right)$ to give 6 [24] as a white solid (yield 75\%) m.p. $224-226^{\circ} \mathrm{C} .{ }^{1} \mathrm{H}-\mathrm{NMR}$ (DMSO- $d_{6}$ ) $\delta 0.84$ (t, 3H, $\left.J=7.3 \mathrm{~Hz}, \mathrm{CH}_{2} \mathrm{CH}_{3}\right), 1.79$ (m, 2H, $\left.\mathrm{CH}_{2} \mathrm{CH}_{3}\right), 4.05$ (t, $2 \mathrm{H}$, $\left.J=7.2 \mathrm{~Hz}, \mathrm{~N}-\mathrm{CH}_{2}\right), 7.72\left(\mathrm{~s}, 2 \mathrm{H}, \mathrm{NH}_{2}\right), 8.15(\mathrm{~s}, 1 \mathrm{H}, \mathrm{H}-8)$. Anal. Calcd. for $\mathrm{C}_{8} \mathrm{H}_{10} \mathrm{ClN}_{5}(211.7) \mathrm{C}, 45.40 ; \mathrm{H}, 4.76 ; \mathrm{N}$, 33.09. Found: C, 45.75; H, 4.80; N, 32.87.

\section{General procedure for the preparation} of the $N^{6}$-acylaminoadenine (7-14)

A solution in dry THF $(4 \mathrm{ml})$ of the appropriate acid (1822) $(0.46 \mathrm{mmol})$ and carbonyldiimidazole $(83 \mathrm{mg}$, $0.51 \mathrm{mmol}$ ) was poured at reflux under nitrogen for $1 \mathrm{~h}$. Then the amino compound 5 or $6(0.46 \mathrm{mmol})$ was added and the resulting mixture was refluxed overnight. The solvent was removed under reduced pressure and the crude purified by flash chromatography to afford the desired final compounds 7-14.

\section{6-[(4-Bromophenyl)acetyl]amino-9-propyladenine (7)}

Eluent for chromatography $\mathrm{CHCl}_{3}-\mathrm{MeOH}$ 95:5; yield $59 \%$, white solid; m.p. $149-151^{\circ} \mathrm{C}$ (dec.); ${ }^{1} \mathrm{H}-\mathrm{NMR}$ (DMSO- $d_{6}$ ): $\delta 0.83$ (t, $3 \mathrm{H}, J=7.2 \mathrm{~Hz}, \mathrm{CH}_{2} \mathrm{CH}_{3}$ ), 1.84 (m, 2H, $\left.\mathrm{CH}_{2} \mathrm{CH}_{3}\right), 3.89$ (s, 2H, $\left.\mathrm{CH}_{2}-\mathrm{CO}\right), 4.19$ (t, $2 \mathrm{H}, J=$ $\left.7.1 \mathrm{~Hz}, \mathrm{~N}-\mathrm{CH}_{2}\right), 7.30$ (d, 2H, J=8.4 Hz, H-Ph), 7.51 (d, $2 \mathrm{H}, J=8.4 \mathrm{~Hz}, \mathrm{H}-\mathrm{Ph}$ ), 8.47 (s, 1H, H-8), 8.62 (s, 1H, H-2), $10.91(\mathrm{~s}, 1 \mathrm{H}, \mathrm{NH})$. Anal. Calcd. for $\mathrm{C}_{16} \mathrm{H}_{16} \mathrm{BrN}_{5} \mathrm{O}(374.2)$ C, 51.35; H, 4.31; N, 18.71. Found: C, 51.65; H, 4.80; N, 18.50 .

6-[(4-Bromophenyl)acetyl] amino-2-chloro-9propyladenine $(\boldsymbol{8})$

Eluent for chromatography $\mathrm{CHCl}_{3}-\mathrm{cC}_{6} \mathrm{H}_{12}$ 80:20; yield $26 \%$, white solid; m.p. $164-166^{\circ} \mathrm{C} ;{ }^{1} \mathrm{H}-\mathrm{NMR}$ (DMSO- $d_{6}$ ): $\delta 0.84$ (t, $\left.3 \mathrm{H}, J=7.5 \mathrm{~Hz}, \mathrm{CH}_{2} \mathrm{CH}_{3}\right), 1.83\left(\mathrm{~m}, 2 \mathrm{H}, \mathrm{CH}_{2} \mathrm{CH}_{3}\right.$ ), $3.88\left(\mathrm{~s}, 2 \mathrm{H}, \mathrm{CH}_{2}-\mathrm{CO}\right), 4.15$ (t, $\left.2 \mathrm{H}, J=6.9 \mathrm{~Hz}, \mathrm{~N}^{-C_{2}}\right), 7.30$ (d, 2H, $J=8.4 \mathrm{~Hz}, \mathrm{H}-\mathrm{Ph}$ ), 7.53 (d, 2H, $J=8.4 \mathrm{~Hz}, \mathrm{H}-\mathrm{Ph}$ ), $8.50(\mathrm{~s}, 1 \mathrm{H}, \mathrm{H}-8), 11.25$ (s, 1H, NH). Anal. Calcd. for $\mathrm{C}_{16} \mathrm{H}_{15} \mathrm{BrClN}_{5} \mathrm{O}$ (408.7) C, 47.02; H, 3.70; N, 17.14. Found: C, 47.49; H, 3.83; N, 17.40 .

6-[(4-(4-Bromobenzyloxy)phenyl)acetyl]amino-9propyladenine $(\mathbf{9})$

Eluent for chromatography $\mathrm{CHCl}_{3}-\mathrm{MeOH}$ 95:5; yield 58\%, white solid; m.p. $154-156{ }^{\circ} \mathrm{C} ;{ }^{1} \mathrm{H}-\mathrm{NMR}$ (DMSO- $d_{6}$ ): $\delta 0.85$ (t, $\left.3 \mathrm{H}, J=7.5 \mathrm{~Hz}, \mathrm{CH}_{2} \mathrm{CH}_{3}\right), 1.85\left(\mathrm{~m}, 2 \mathrm{H}, \mathrm{CH}_{2} \mathrm{CH}_{3}\right), 3.82$ (s, $2 \mathrm{H}, \mathrm{CH}_{2}-\mathrm{CO}$ ), 4.21 (t, $1 \mathrm{H}, J=7.0 \mathrm{~Hz}, \mathrm{~N}_{-} \mathrm{CH}_{2}$ ), 5.07 (s, $\left.2 \mathrm{H}, \mathrm{CH}_{2}-\mathrm{O}\right), 6.95$ (d, 2H, $\left.J=8.8 \mathrm{~Hz}, \mathrm{H}-\mathrm{Ph}\right), 7.27$ (d, 2H, $J=$ $8.4 \mathrm{~Hz}, \mathrm{H}-\mathrm{Ph}), 7.40$ (d, 2H, J=8.4 Hz, H-Ph), 7.58 (d, 2H, 
$J=8.4 \mathrm{~Hz}, \mathrm{H}-\mathrm{Ph}), 8.48(\mathrm{~s}, 1 \mathrm{H}, \mathrm{H}-8), 8.62(\mathrm{~s}, 1 \mathrm{H}, \mathrm{H}-2)$, 10.81 (s, $1 \mathrm{H}, \mathrm{NH})$. Anal. Calcd. for $\mathrm{C}_{23} \mathrm{H}_{22} \mathrm{BrN}_{5} \mathrm{O}_{2}(480.4)$ C, 57.51; H, 4.62; N, 14.58. Found: C, 57.99; H, 4.66; N, 14.55 .

6-[(4-(4-Bromobenzyloxy)phenyl)acetyl] amino-2-chloro-9propyladenine (10)

Eluent for chromatography $\mathrm{CHCl}_{3}-\mathrm{cC}_{6} \mathrm{H}_{12}-\mathrm{MeOH}$ 50:48:2; yield $14 \%$, white solid; m.p. $176-178^{\circ} \mathrm{C} ;{ }^{1} \mathrm{H}-\mathrm{NMR}$ (DMSO- $d_{6}$ ): $\delta 0.81$ (t, $\left.3 \mathrm{H}, J=7.5 \mathrm{~Hz}, \mathrm{CH}_{2} \mathrm{CH}_{3}\right), 1.79$ (m, $2 \mathrm{H}, \mathrm{CH}_{2} \mathrm{CH}_{3}$ ), 3.76 (s, $2 \mathrm{H}, \mathrm{CH}_{2}-\mathrm{CO}$ ), 4.12 (t, $2 \mathrm{H}, J=$ $\left.7.4 \mathrm{~Hz}, \mathrm{~N}-\mathrm{CH}_{2}\right), 5.03\left(\mathrm{~s}, 2 \mathrm{H}, \mathrm{CH}_{2}-\mathrm{O}\right), 6.92(\mathrm{~d}, 2 \mathrm{H}, J=$ $8.6 \mathrm{~Hz}, \mathrm{H}-\mathrm{Ph}), 7.22$ (d, 2H, J=8.4 Hz, H-Ph), 7.36 (d, 2H, $J=8.4 \mathrm{~Hz}, \mathrm{H}-\mathrm{Ph}), 7.54$ (d, 2H, $J=8.4 \mathrm{~Hz}, \mathrm{H}-\mathrm{Ph}), 8.46$ (s, $1 \mathrm{H}, \mathrm{H}-8), 11.11(\mathrm{~s}, 1 \mathrm{H}, \mathrm{NH})$. Anal. Calcd. for $\mathrm{C}_{23} \mathrm{H}_{21} \mathrm{BrClN}_{5} \mathrm{O}_{2}$ (514.8) C, 53.66; H, 4.11; N, 13.60 . Found: C, 53.75; H, 4.25; N, 13.29 .

\section{6-[(4-(4-Methylbenzyloxy)phenyl)acetyl] amino-9- propyladenine (11)}

Eluent for chromatography $\mathrm{CHCl}_{3}-\mathrm{cC}_{6} \mathrm{H}_{12}-\mathrm{MeOH}$ 70:28:2; yield $35 \%$, white solid; m.p. $131-132{ }^{\circ} \mathrm{C} ;{ }^{1} \mathrm{H}$-NMR (DMSO$\left.d_{6}\right): \delta 0.83\left(\mathrm{t}, 3 \mathrm{H}, J=7.3 \mathrm{~Hz}, \mathrm{CH}_{2} \mathrm{CH}_{3}\right), 1.84(\mathrm{~m}, 2 \mathrm{H}$, $\left.\mathrm{CH}_{2} \mathrm{CH}_{3}\right), 2.28\left(\mathrm{~s}, 3 \mathrm{H}, \mathrm{CH}_{3}-\mathrm{Ph}\right), 3.80\left(\mathrm{~s}, 2 \mathrm{H}, \mathrm{CH}_{2}-\mathrm{CO}\right)$, 4.20 (t, $2 \mathrm{H}, J=7.1 \mathrm{~Hz}, \mathrm{~N}-\mathrm{CH}_{2}$ ), 5.02 (s, $\left.2 \mathrm{H}, \mathrm{CH}_{2}-\mathrm{O}\right), 6.93$ (d, $2 \mathrm{H}, J=8.4 \mathrm{~Hz}, \mathrm{H}-\mathrm{Ph}$ ), 7.24 (m, 6H, H-Ph), 8.47 (s, $1 \mathrm{H}$, $\mathrm{H}-8), 8.62$ (s, 1H, H-2), 10.83 (s, 1H, NH). Anal. Calcd. for $\mathrm{C}_{24} \mathrm{H}_{25} \mathrm{~N}_{5} \mathrm{O}_{2}$ (415.5) $\mathrm{C}, 69.38 ; \mathrm{H}, 6.06 ; \mathrm{N}, 16.86$. Found: $\mathrm{C}$, 69.74; H, 6.35; N, 16.54 .

\section{6-[(4-Benzyloxyphenyl)acetyl] amino-9-propyladenine (12)}

Eluent for chromatography $\mathrm{CHCl}_{3}-\mathrm{MeOH}$ 97:3; yield 52\%, white solid; m.p. $121-123^{\circ} \mathrm{C}$; ${ }^{1} \mathrm{H}-\mathrm{NMR}$ (DMSO- $d_{6}$ ): $\delta 0.83$ (t, $\left.3 \mathrm{H}, J=7.5 \mathrm{~Hz}, \mathrm{CH}_{2} \mathrm{CH}_{3}\right), 1.84\left(\mathrm{~m}, 2 \mathrm{H}, \mathrm{CH}_{2} \mathrm{CH}_{3}\right), 3.80$ (s, 2H, $\mathrm{CH}_{2}-\mathrm{CO}$ ), 4.19 (t, $2 \mathrm{H}, J=7.1 \mathrm{~Hz}, \mathrm{~N}_{-} \mathrm{CH}_{2}$ ), 5.07 (s, $\left.2 \mathrm{H}, \mathrm{CH}_{2}-\mathrm{O}\right), 6.95$ (d, 2H, J=8.4 Hz, H-Ph), 7.25 (d, 2H, $J=$ $8.8 \mathrm{~Hz}, \mathrm{H}-\mathrm{Ph}$ ), 7.37 (m, 5H, H-Ph), 8.47 (s, 1H, H-8), 8.62 (s, 1H, H-2), $10.82(\mathrm{~s}, 1 \mathrm{H}, \mathrm{NH})$. Anal. Calcd. for $\mathrm{C}_{23} \mathrm{H}_{23} \mathrm{~N}_{5} \mathrm{O}_{2}$ (401.5) $\mathrm{C}, 68.81 ; \mathrm{H}, 5.77 ; \mathrm{N}, 17.44$. Found: C, 68.97; H, 5.89; N, 17.35.

\section{6-[(4-Benzyloxyphenyl)acetyl] amino-2-chloro-9- propyladenine (13)}

Eluent for chromatography $\mathrm{CHCl}_{3}-\mathrm{MeOH}$ 99:1; yield $17 \%$, white solid; m.p. $150-152{ }^{\circ} \mathrm{C}$; ${ }^{1} \mathrm{H}-\mathrm{NMR}$ (DMSO- $d_{6}$ ): $\delta 0.84$ (t, $\left.3 \mathrm{H}, J=7.3 \mathrm{~Hz}, \mathrm{CH}_{2} \mathrm{CH}_{3}\right), 1.82\left(\mathrm{~m}, 2 \mathrm{H}, \mathrm{CH}_{2} \mathrm{CH}_{3}\right), 3.79$ (s, 2H, $\mathrm{CH}_{2}-\mathrm{CO}$ ), 4.14 (t, 2H, J=7.0 Hz, N-CH $\left.\mathrm{CH}_{2}\right), 5.07$ (s, $\left.2 \mathrm{H}, \mathrm{CH}_{2}-\mathrm{O}\right), 6.95(\mathrm{~d}, 2 \mathrm{H}, J=8.6 \mathrm{~Hz}, \mathrm{H}-\mathrm{Ph}), 7.25(\mathrm{~d}, 2 \mathrm{H}, J=$ $8.4 \mathrm{~Hz}, \mathrm{H}-\mathrm{Ph}$ ), 7.37 (m, 5H, H-Ph), 8.49 (s, 1H, H-8), 11.16 (s, 1H, NH). Anal. Calcd. for $\mathrm{C}_{23} \mathrm{H}_{22} \mathrm{ClN}_{5} \mathrm{O}_{2}$ (435.9) $\mathrm{C}$, 63.37; H, 5.09; N, 16.07. Found: C, 63.56; H, 5.14; N, 15.76 .

6-\{[(4-Methoxybenzyloxy)phenyl]acetyl $\}$ amino-2-chloro-9propyladenine (14)

Eluent for chromatography $\mathrm{CHCl}_{3}-\mathrm{MeOH}$ 99:1; yield 29\%, white solid; m.p. $174-176^{\circ} \mathrm{C} ;{ }^{1} \mathrm{H}-\mathrm{NMR}$ (DMSO- $d_{6}$ ): $\delta 0.84$ (t, $\left.3 \mathrm{H}, J=7.4 \mathrm{~Hz}, \mathrm{CH}_{2} \mathrm{CH}_{3}\right), 1.82\left(\mathrm{~m}, 2 \mathrm{H}, \mathrm{CH}_{2} \mathrm{CH}_{3}\right), 3.73$ (s, $3 \mathrm{H}, \mathrm{CH}_{3}-\mathrm{O}$ ), 3.79 (s, $\left.3 \mathrm{H}, \mathrm{CH}_{2}-\mathrm{CO}\right), 4.14$ (t, $2 \mathrm{H}, J=$ $\left.7.0 \mathrm{~Hz}, \mathrm{~N}-\mathrm{CH}_{2}\right), 4.98$ (s, 2H, $\left.\mathrm{CH}_{2}-\mathrm{O}\right), 6.92(\mathrm{~d}, 2 \mathrm{H}, J=$ $8.0 \mathrm{~Hz}, \mathrm{H}-\mathrm{Ph}$ ), 6.93 (d, 2H, J=8.4 Hz, H-Ph), 7.24 (d, 2H, $J=8.4 \mathrm{~Hz}, \mathrm{H}-\mathrm{Ph}$ ), 7.35 (d, 2H, $J=8.4 \mathrm{~Hz}, \mathrm{H}-\mathrm{Ph}$ ), 8.49 (s, $1 \mathrm{H}, \mathrm{H}-8), 11.15(\mathrm{~s}, 1 \mathrm{H}, \mathrm{NH})$. Anal. Calcd. for $\mathrm{C}_{24} \mathrm{H}_{24} \mathrm{ClN}_{5} \mathrm{O}_{3}(465.9) \mathrm{C}, 61.87 ; \mathrm{H}, 5.19 ; \mathrm{N}, 15.03$. Found: C, 61.99; H, 5.33; N, 14.91 .

\section{Biology}

All pharmacological methods followed the procedures as described earlier [26]. In brief, membranes for radioligand binding were prepared from $\mathrm{CHO}$ cells stably transfected with human adenosine receptor subtypes in a two-step procedure. In a first low-speed step $(1,000 \mathrm{~g})$ cell fragments and nuclei were removed. The crude membrane fraction was sedimented from the supernatant at $100,000 \mathrm{~g}$. The membrane pellet was resuspended in the buffer used for the respective binding experiments, frozen in liquid nitrogen and stored at $-80^{\circ} \mathrm{C}$. For the measurement of adenylyl cyclase activity only one high speed centrifugation of the homogenate was used. The resulting crude membrane pellet was resuspended in $50 \mathrm{mM}$ Tris/ $\mathrm{HCl}, \mathrm{pH} 7.4$ and immediately used for the cyclase assay.

For radioligand binding at $\mathrm{A}_{1}$ adenosine receptors $1 \mathrm{nM}$ $\left[{ }^{3} \mathrm{H}\right] \mathrm{CCPA}$ was used, whereas 30 and $10 \mathrm{nM}\left[{ }^{3} \mathrm{H}\right] \mathrm{NECA}$ were used for $A_{2 A}$ and $A_{3}$ receptors, respectively. Nonspecific binding of $\left[{ }^{3} \mathrm{H}\right] \mathrm{CCPA}$ was determined in the presence of $1 \mathrm{mM}$ theophylline; in the case of $\left[{ }^{3} \mathrm{H}\right] \mathrm{NECA}$ $100 \mathrm{pM}$ R-PIA was used. $\mathrm{K}_{\mathrm{i}}$ values from competition experiments were calculated with the program SCTFIT [33]. At $\mathrm{A}_{2 \mathrm{~B}}$ adenosine receptors inhibition of NECAstimulated adenylyl cyclase activity was used as a measurement of potency of the new compounds. $\mathrm{IC}_{50}$ values from these experiments were converted to $\mathrm{K}_{\mathrm{i}}$ values with the Cheng and Prusoff equation [34].

Acknowledgements The expert technical assistance of Ms. Sonja Kachler is gratefully acknowledged. This work was supported by Fondo di Ricerca di Ateneo (University of Camerino) and by grants from the Italian Ministry of Research: FIRB 2003, and PRIN 2005. 


\section{References}

1. Cristalli G, Volpini R (eds) (2003) Adenosine receptors: medicinal chemistry, pharmacology and therapeutic applications. Curr Top Med Chem 3:355-469

2. Robeva AS, Woodard RL, Ji XD, Gao Z, Bhattacharya S, Taylor HE, Rosin DL, Linden J (1996) Molecular characterization of recombinant human adenosine receptors. Drug Dev Res 39:243-252

3. Fredholm BB, IJzerman AP, Klotz K-N, Linden J (2001) International Union of Pharmacology. XXV. Nomenclature and classification of adenosine receptors. Pharmacol Rev 53:527-533

4. Jacobson MJ (2002) Adenosine receptor agonists. Expert Opin Ther Pat 12:489-501

5. Feoktistov I, Biaggioni I (1995) Adenosine $A_{2 B}$ receptors evoke interleukin-8 secretion in human mast cells. An enprofyllinesensitive mechanism with implications for asthma. J Clin Invest 96:1979-1986

6. Marquardt DL, Walker LL, Heinemann S (1994) Cloning of two adenosine receptor subtypes from mouse bone marrow-derived mast cells. J Immunol 152:4508-4515

7. Boyle DL, Sajjadi FG, Firestein GS (1996) Inhibition of synoviocyte collagenase gene expression by adenosine receptor stimulation. Arthritis Rheum 39:923-930

8. Fiebich BL, Biber K, Guipko K, Berger M, Bauer J, van Calker D (1996) Adenosine $A_{2 B}$ receptors mediate an increase in interleukin (IL)-6 mRNA and IL-6 protein synthesis in human astroglioma cells. J Neurochem 66:1426-1431

9. Dubey RK, Gillaspie DG, Osaka K, Suzuki F, Jackson EK (1996) Adenosine inhibits growth of rat aortic smooth muscle cells: possible role of $\mathrm{A}_{2 \mathrm{~B}}$ receptors. Hypertension 27:786-793

10. Feoktistov I, Biaggioni I (1997) Adenosine $A_{2 B}$ receptors. Pharmacol Rev 49:381-402

11. Feoktistov I, Wells JN, Biaggioni I (1998) Adenosine $A_{2 B}$ receptors as therapeutic targets. Drug Dev Res 45:198-206

12. Feoktistov I, Biaggioni I (1998) Pharmacological characterization of adenosine $\mathrm{A}_{2 \mathrm{~B}}$ receptors. Biochem Pharmacol 55:627-633

13. Beukers MW, Meurs I, IJzerman AP (2006) Structure affinity relationships of adenosine $\mathrm{A}_{2 \mathrm{~B}}$ receptor ligands. Med Res Rev 26:667-698

14. Kim YC, Ji X-D, Melman N, Linden J, Jacobson KA (2000) Anilide derivatives of an 8-phenylxanthine carboxylic congener are highly potent and selective antagonists at human $\mathrm{A}_{2 \mathrm{~B}}$ adenosine receptors. J Med Chem 43:1165-1172

15. Kalla RV, Elzein E, Perry T, Li X, Palle V, Varkhedkar V, Gimbeò A, Maa T, Zang D, Zablocki J (2006) Novel 1,3disubstituted 8-(1-benzyl-1H-pyrazol-4-yl) xanthines: high affinity and selective $\mathrm{A}_{2 \mathrm{~B}}$ adenosine receptor antagonists. J Med Chem 49:3682-3692

16. Pastorin G, Da Ros T, Spalluto G, Deflorian F, Moro S, Cacciari B, Baraldi PG, Gessi S, Varani K, Borea PA (2003) Pyrazolo[4,3e]-1,2,4-triazolo[1,5-c]pyrimidine derivatives as adenosine receptor antagonists. Influence of the N5 substituent on the affinity at the human $\mathrm{A}_{3}$ and $\mathrm{A}_{2 \mathrm{~B}}$ adenosine receptor subtypes: a molecular modeling investigation. J Med Chem 46:4287-4296

17. Vidal B, Nueda A, Esteve C, Domenech T, Benito S, Renoso RF, Pont M, Calbet M, Lopez R, Cadavid MI, Loza MI, Cardenas A, Godessart N, Beleta J, Warzelow G, Ryder H (2007) Discovery and characterization of 4'-(2-furyl)-N-pyridin-3-yl-4,5'bipyrimidin-2'-amine (LAS38096), a potent and efficacious $\mathrm{A}_{2 \mathrm{~B}}$ adenosine receptor antagonist. J Med Chem 50:2732-2736

18. Cristalli G, Camaioni E, Costanzi S, Vittori S, Volpini R, Klotz KN (1998) Characterization of potent ligands at human recombinant adenosine receptors. Drug Dev Res 45:176-181
19. Camaioni E, Costanzi S, Vittori S, Volpini R, Klotz KN, Cristalli G (1998) New substituted 9-alkylpurines as adenosine receptor ligands. Bioorg Med Chem 6:523-533

20. Klotz KN, Kachler S, Lambertucci C, Vittori S, Volpini R, Cristalli G (2003) 9-Ethyladenine derivatives as adenosine receptor antagonists: 2- and 8-substitution results in distinct selectivities. Naunyn Schmiedeberg's Arch Pharmacol 367:629634

21. Volpini R, Costanzi S, Vittori S, Cristalli G, Klotz K-N (2003) Medicinal chemistry and pharmacology of $\mathrm{A}_{2 \mathrm{~B}}$ adenosine receptors. Curr Top Med Chem 3:427-443

22. Volpini R, Costanzi S, Lambertucci C, Vittori S, Martini C, Trincavelli ML, Klotz K-N, Cristalli G (2005) 2- And 8-alkynyl9-ethyladenines: synthesis and biological activity at human and rat adenosine receptors. Purinergic Signalling 1:173-181

23. Zhang L, Fan J, Vu K, Hong K, Le Brazidec JY, Shi J, Biamonte M, Busch DJ, Lough RE, Grecko R, Ran Y, Sensintaffar JL, Camal A, Lundgren K, Burrows FJ, Mansfield R, Timony GA, Ulm EH, Kasibhatla SR, Boehm M (2006) 7'-Substituted benzothiazolothio- and pyridinothiazolothio-purines as potent heat shock protein 90 inhibitors. J Med Chem 49:5352-5362

24. Maruyama T, Kozai S, Sasaki F (1998) Methods for the synthesis of uric acid derivatives. Nucleosides Nucleotides Nucleic Acids 19:1193-1203

25. Karaneswsky C, Thomson D, Michellys A, Ruppar P, Chen JH (2005) Preparation of benzoic acid phenylacetic derivatives as HNT $-4^{\circ}$ modulators. PCT Int. Appl. WO200500910420040716

26. Klotz KN, Hessling J, Hegler J, Owman C, Kull B, Fredholm BB, Lohse MJ (1998) Comparative pharmacology of human adenosine receptor subtypes - characterization of stably transfected receptors in CHO cells. Naunyn Schmiedeberg's Arch Pharmacol 357:1-9

27. Baraldi PG, Cacciari B, Pineda de las Infantas MJ, Romagnoli R, Spalluto G, Volpini R, Costanzi S, Vittori S, Cristalli G, Melman N, Park K, Jacobson KA (1998) Synthesis and biological activity of a new series of $N^{6}$-arylcarbamoyl-,2-(ar)alkynyl- $N^{6}$-arylcarbamoyl- and $N^{6}$-carboxamido-adenosine-5'-uronamides as $\mathrm{A}_{3}$ adenosine receptor agonists. J Med Chem 41:3174-3185

28. Volpini R, Camaioni E, Costanzi S, Vittori S, Klotz K-N, Cristalli G (1999) Synthesis of di- and tri-substituted adenosine derivatives and their affinities at human adenosine receptor subtypes. Nucleosides Nucleotides 18:2511-2520

29. Volpini R, Costanzi S, Lambertucci C, Taffi S, Vittori S, Klotz KN, Cristalli G (2002) $N^{6}$-Alkyl-2-alkynyl derivatives of adenosine as potent and selective agonists at the human adenosine $\mathrm{A}_{3}$ receptor and a starting point for searching $\mathrm{A}_{2 \mathrm{~B}}$ ligands. $\mathrm{J}$ Med Chem 45:3271-3279

30. Cristalli G, Lambertucci C, Taffi S, Vittori S, Volpini R (2003) Medicinal chemistry of adenosine $\mathrm{A}_{2 \mathrm{~A}}$ receptor agonists. Curr Top Med Chem 3:387-401

31. Volpini R, Dal Ben D, Lambertucci C, Taffi S, Vittori S, Klotz KN, Cristalli G (2007) $N^{6}$-methoxy-2-alkynyladenosine derivatives as highly potent and selective ligands at the human $\mathrm{A}_{3}$ adenosine receptor. J Med Chem 50:1222-1230

32. Cristalli G, Cacciari B, Dal Ben D, Lambertucci C, Moro S, Spalluto G, Volpini R (2007) Medicinal chemistry of adenosine $\mathrm{A}_{2 \mathrm{~A}}$ receptor agonists. Chem Med Chem 2:260-281

33. De Lean A, Hancock AA, Lefkowitz RJ (1982) Validation and statistical analysis of a computer modeling method for quantitative analysis of radioligand binding data for mixtures of pharmacological receptor subtypes. Mol Pharmacol 21:5-16

34. Cheng YC, Prusoff WH (1973) Relationship between the inhibition constant $\left(\mathrm{K}_{\mathrm{i}}\right)$ and the concentration of inhibitor which causes 50 per cent inhibition $\left(\mathrm{I}_{50}\right)$ of an enzymatic reaction. Biochem Pharmacol 22:3099-3108 